\title{
Penapisan Aktivitas Selulase Isolat-isolat Khamir dari Moluska, Serasah, dan Tumbuhan di Taman Nasional Gunung Halimun, Jawa Barat
}

\author{
Screening Cellulase Activity of Yeast Isolates from Mollusc, Litter and Plant samples \\ from Taman Nasional Gunung Halimun, West Java
}

Wibowo Mangunwardoyo*, Reno Fitri, Ariyanti Oetari

Departemen Biologi, Fakultas Matematika dan IlmuPengetahuan Alam, Universitas Indonesia, Depok, 16424

E-mail:w_mangunwardoyo@hotmail.com*Penulis untuk korespondensi

\begin{abstract}
A total of 236 yeast isolates from mollusc, litter, and plant samples from Gunung Halimun National Park were screened for cellulolytic activity based on Smith method by using $0,2 \%(w / v)$ cellulose-azure for 30 days. The results showed that 12 isolates (9 isolates from plants, 2 isolates from molluscs, dan 1 isolate from litter) have cellulolytic activity. These isolates were further screened based on Teather and Wood method for six days to determine their cellulases components by using specific substrates. Carboxymethyl cellulose (CMC) $0,1 \%$ (w/v) was used as a specific substrate to determine endoglucanase activity. Avicel $0,1 \%$ (w/v) was used as a specific substrate to determine exoglucanase activity. Cellobiose $0,1 \%(\mathrm{w} / \mathrm{v})$ was used as a specific substrate to determine $\beta$-glucosidase activity. The results showed that 6 isolates from plant have $\beta$-glucosidase activity, and 1 isolate from plant have $\beta$ glucosidase and endoglucanase activities. Five isolates ( 2 isolates from plants, 2 isolates from molluscs, and 1 isolate from litter) showed no cellulase activity on specific substrates after six days incubation.
\end{abstract}

Key words: $\beta$-glucosidase, cellulolytic activity, endoglucanase, exoglucanase, yeast

Diterima: 03 Agustus 2007, disetujui: 02 Oktober 2007

\section{Pendahuluan}

Selulosa adalah polisakarida yang disusun oleh unit-unit glukosa, dan membentuk polimer melalui ikatan $\beta$-1,4-glikosida (Bayer et al., 1998). Selulase merupakan enzim penghidrolisis selulosa terdiri dari tiga komponen, yaitu endoglukanase (EC 3.2.1.4), eksoglukanase (EC 3.2.1.91), dan $\beta$-glukosidase (EC 3.2.1.21) (Onsori et al., 2005). Beberapa jenis khamir menghasilkan selulase, misalnya Candida pelliculosa, $C$. peltata dan $C$. wickerhamii menghasilkan $\beta$-glukosidase (Saha \& Bothast, 1996). Sudiana dan Rahmansyah (2002) mengisolasi 20 isolat khamir dari tanah Taman Nasional Gunung Halimun (TNGH), penghasil endoglukanase. Aprilismulan (2005) melaporkan bahwa isolat-isolat khamir TNGH koleksi UICC menghasilkan endoglukanase atau $\beta$-glukosidase, dan beberapa isolat dapat menghasilkan kedua komponen selulase tersebut. Strain Trichosporon sporotrichoides (van Oorschot) van Oorschot \& de Hoog UICC Y-286 menghasilkan ketiga komponen selulase. University of Indonesia Culture Collection (UICC) telah mengisolasi khamir dari moluska, serasah, dan tumbuhan yang hidup di (TNGH), Jawa Barat. Penapisan aktivitas selulase bertujuan untuk mencari isolat-isolat baru yang dapat menghasilkan selulase dihasilkan isolatisolat khamir TNGH.

\section{Metode Penelitian}

\section{Khamir}

Khamir yang diuji sebanyak 236 isolat, koleksi UICC dari moluska, serasah, dan 
tumbuhan Taman Nasional Gunung Halimun, Jawa Barat. Khamir isolat P2112 dari tumbuhan Cagar Alam Muara Angke sebagai kontrol positif. Khamir Saccharomyces cerevisiae var. ellipsoideus Meyen ex Hansen UICC Y-17 kontrol negatif.

Medium penapisan aktivitas selulase dengan substrat selulosa-azur $0,2 \%(b / v)$

Medium penapisan aktivitas selulase dengan substrat selulosa-azur $0,2 \%$ dibuat berdasarkan Smith (1977) yang dimodifikasi. Medium tersebut terdiri dari dua lapisan. Lapisan bawah berupa agar $0,75 \%$. Lapisan atas berupa campuran Yeast Nitrogen Base Agar (YNBA) dan selulosa-azur 0,2\%. Bagian atas medium berupa campuran medium basal Yeast Nitrogen Base Agar (YNBA) dengan selulosa azur 0,2\%. Medium YNBA dibuat berdasarkan van der Walt dan Yarrow (1984). Kedua medium dicampur secara aseptis ketika masih hangat, dan divorteks hingga homogen. Sebanyak 0,5 $\mathrm{ml}$ campuran medium tersebut dimasukkan ke dalam tabung berisi agar $0,75 \%$, medium dibiarkan mengeras dalam posisi tegak.

\section{Medium penapisan yang mengandung substrat spesifik}

Medium penapisan aktivitas selulase yang mengandung substrat spesifik dibuat berdasarkan Teather dan Wood (1982). Sebanyak $0,1 \%$ substrat CMC, Avisel, dan selobiosa ditambahkan ke dalam setiap medium YNBA. Sebanyak kurang lebih $15 \mathrm{ml}$ medium yang telah steril dituang ke dalam cawan petri, dan didiamkan hingga mengeras. Cawan petri dibagi menjadi empat bagian kemudian agar dari masing-masing bagian dilubangi bagian tengahnya menggunakan silinder kaca steril berdiameter luar $0,8 \mathrm{~cm}$.

\section{Penapisan aktivitas selulase pada medium selulosa azur}

Sebanyak $100 \mu \mathrm{l}\left(0,30-3,00 \times 10^{8} \mathrm{sel} / \mathrm{ml}\right)$ suspensi sel khamir diinokulasikan ke dalam medium selulosa-azur dan diinkubasi selama 30 hari pada suhu ruang $\left(20-25^{\circ} \mathrm{C}\right)$. Pengamatan aktivitas selulase dilakukan setiap hari. Aktivitas selulase ditandai dengan adanya difusi azur ke dalam agar. Pengamatan dilakukan dengan cara melihat ada atau tidak adanya difusi azur ke dalam agar, mengukur jarak difusi azur menggunakan jangka sorong, dan membandingkan intensitas warna azur yang berdifusi ke dalam agar.

\section{Penapisan aktivitas selulase pada substrat spesifik}

Penapisan aktivitas selulase pada substrat spesifik dilakukan terhadap isolat-isolat khamir yang menunjukkan aktivitas selulase pada penapisan dengan medium selulosa-azur. Sebanyak $30 \mu$ l suspensi sel khamir $(0,30-3,00$ x $10^{8} \mathrm{sel} / \mathrm{ml}$ ) diinokulasikan ke dalam lubang pada medium penapisan yang mengandung substrat spesifik, diinkubasi pada suhu ruang $\left(20-25^{\circ} \mathrm{C}\right)$ selama enam hari. Pada hari keenam, seluruh permukaan medium penapisan yang telah diinokulasi khamir ditetesi Congo red steril $0,2 \%$, dan didiamkan selama 15 menit hingga Congo red meresap ke dalam medium. Biakan yang telah ditetesi Congo red diinkubasi selama 24 jam. Zona bening akan terbentuk di sekitar isolat khamir yang memiliki aktivitas CMC-ase (endoglukanase), Aviselase (eksoglukanase), dan selobiase ( $\beta$-glukosidase).

\section{Pengukuran indeks aktivitas selulase}

Indeks aktivitas selulase (IAS) diperoleh dengan rumus sebagai berikut (Kader \& Omar, 1998):

IAS $=\frac{\text { Diameter zona bening }- \text { Diameter koloni khamir }}{\text { Diameter koloni khamir }}$

Indeks aktivitas selulase yang tinggi mengindikasikan bahwa isolat khamir tersebut mempunyai aktivitas selulase tinggi.

\section{Hasil dan Pembahasan}

\section{Penapisan aktivitas selulase menggunakan selulosa-azur $0,2 \%$}

Penapisan aktivitas selulase 236 isolat khamir UICC dari moluska (81 isolat), serasah (45 isolat), dan tumbuhan (110 isolat) TNGH dengan metode Smith (1977) menggunakan selulosa-azur $0,2 \% \quad(\mathrm{~b} / \mathrm{v})$ dapat dilihat pada Tabel 1. Hasil penapisan menunjukkan sebanyak 12 isolat khamir TNGH memiliki aktivitas 
selulase karena dapat melepaskan ikatan azur dengan selulosa, sehingga azur berdifusi ke dalam agar dan mengubah warna medium agar.

Konsentrasi selulosa-azur yang digunakan dalam penelitian adalah $0,2 \%(\mathrm{~b} / \mathrm{v})$. Penapisan aktivitas selulase khamir koleksi UICC menggunakan $0,2 \% \quad(\mathrm{~b} / \mathrm{v})$ selulosa-azur juga pernah dilakukan oleh Fanny (2004), Yosylina (2004), dan Aprilismulan (2005). Hasil penelitian menunjukkan bahwa selulosa-azur dengan konsentrasi $0,2 \%$ sudah dapat mengindikasikan adanya aktivitas selulase, yaitu dengan terdeteksinya difusi azur pada medium agar. Konsentrasi tersebut lebih rendah dibandingkan konsentrasi selulosa-azur yang digunakan Smith (1977), yaitu sebanyak $2 \%(\mathrm{~b} / \mathrm{v})$.

Smith (1977) melaporkan bahwa intensitas difusi azur ke dalam agar dapat dijadikan indikasi aktivitas selulase dari isolat-isolat yang diuji. Semakin tinggi intensitas difusi azur menunjukkan semakin tinggi kemampuan suatu isolat menghasilkan selulase, sehingga semakin banyak azur yang dilepaskan dari selulosa dan berdifusi ke dalam agar. Intensitas difusi azur pada Tabel 1 dilambangkan dengan tanda(+) dihasilkan oleh tiga isolat, yaitu P412, P414 dan P4116. Ketiga isolat menghasilkan difusi pada hari ke-5. Intensitas difusi azur dengan tanda (++), dihasilkan oleh enam isolat, yaitu M4148, P413, P415, P4139, P4240, dan P4319.Empat isolat di antaranya, yaitu M4148, P413, P415, dan P4240, menghasilkan difusi pada hari ke-5, sedangkan isolat P4319 pada hari ke-7, dan isolat P4139 pada hari ke-14. Intensitas difusi azur dengan tanda (+++), dihasilkan oleh satu isolat, yaitu M4151 pada hari ke-14. Intensitas difusi azur tertinggi, yaitu ungu tua, dengan tanda (++++), dihasilkan oleh dua isolat, yaitu P411 pada hari ke-5 dan L4225 pada hari ke-12.

Tabel 1. Data hasil penapisan aktivitas selulase dengan metode Smith (1977) menggunakan substrat selulosaazur $0,2 \%(\mathrm{~b} / \mathrm{v})$

\begin{tabular}{|c|c|c|c|c|c|c|}
\hline \multirow[t]{2}{*}{ No } & \multirow[t]{2}{*}{ Kode Isolat } & \multicolumn{4}{|c|}{ Waktu \& Intensitas Difusi (Hari Ke-) } & \multirow{2}{*}{$\begin{array}{l}\text { Karakter Isolat Umur } 30 \text { Hari Dalam Medium } \\
\text { PDA Diinkubasi Pada Suhu Ruang }\left(20-25^{\circ} \mathrm{C}\right)\end{array}$} \\
\hline & & 5 & 7 & 12 & 14 & \\
\hline 1 & L4225 & ב- & ב- & +4+++ & $+4+++$ & berfilamen \\
\hline 2 & M4148 & ++ & ++ & ++ & ++ & berfilamen \\
\hline 3 & M4151 & - & - & - & +++ & berfilamen \\
\hline 4 & P411 & ++++ & ++++ & ++++ & ++++ & $\begin{array}{l}\text { koloni berwarna cokelat, memiliki tubuh buah, } \\
\text { dan berfilamen }\end{array}$ \\
\hline 5 & P412 & + & + & + & + & $\begin{array}{l}\text { koloni berwarna cokelat, memiliki tubuh buah, } \\
\text { dan berfilamen }\end{array}$ \\
\hline 6 & P413 & ++ & ++ & ++ & ++ & $\begin{array}{l}\text { koloni berwarna cokelat, memiliki tubuh buah, } \\
\text { dan berfilamen }\end{array}$ \\
\hline 7 & P414 & + & + & + & + & $\begin{array}{l}\text { koloni berwarna cokelat, memiliki tubuh buah, } \\
\text { dan berfilamen }\end{array}$ \\
\hline 8 & P415 & ++ & ++ & ++ & ++ & $\begin{array}{l}\text { koloni berwarna jingga, memiliki tubuh buah, } \\
\text { dan berfilamen }\end{array}$ \\
\hline 9 & P4116 & + & + & + & + & $\begin{array}{l}\text { koloni berwarna putih agak krem dan tidak } \\
\text { berfilamen }\end{array}$ \\
\hline 10 & P4139 & - & - & - & ++ & koloni berwarna krem dan berfilamen \\
\hline 11 & P4240 & ++ & ++ & ++ & ++ & Koloni berwarna cokelat muda dan berfilamen \\
\hline 12 & $\begin{array}{l}\text { P4319 } \\
\text { P2112 }\end{array}$ & - & ++ & ++ & ++ & Koloni berwarna putih dan berfilamen \\
\hline 13 & $\begin{array}{l}\text { Kontrol }(+) \\
\text { UICC Y-17 }\end{array}$ & + & + & + & + & Koloni berwarna cokelat muda dan berfilamen \\
\hline 14 & Kontrol (-) & - & - & - & - & Koloni berwarna putih \\
\hline
\end{tabular}

Keterangan: L berarti isolat berasal dari serasah; $\mathrm{M}$ berarti isolat berasal dari moluska; $\mathrm{P}$ berarti isolat berasal dari tumbuhan. Tanda $(+)$ menunjukkan intensitas difusi azur ke dalam agar $(+)$ : ungu sangat pucat; $(++)$ : ungu pucat; $(+++)$ : ungu; $(++++)$ : ungu tua; (-): difusi tidak terdeteksi 
Hasil Tabel 1 juga menunjukkan intensitas azur dan waktu yang dibutuhkan untuk berdifusi dari 12 isolat penghasil selulase berdasarkan metode Smith (1977). Sebanyak delapan isolat (M4148, P411, P412, P413, P414, $\mathrm{P} 415$, P4116, dan P4240) menghasilkan difusi dengan waktu paling cepat (5 hari) tetapi intensitas difusi azur isolat P411 lebih tinggi dibandingkan tujuh isolat lainnya. Isolat P411 dan L4225 memiliki intensitas difusi azur sama (ungu tua), tetapi waktu yang dibutuhkan isolat P411 untuk menghasilkan difusi (5 hari) lebih cepat dibandingkan isolat L4225 (12 hari). Smith (1977) melaporkan bahwa selain intensitas difusi azur, waktu yang dibutuhkan untuk menghasilkan difusi azur dapat digunakan sebagai ukuran kemampuan suatu isolat menghasilkan selulase. Hasil pengamatan intensitas difusi azur dan waktu difusi menunjukkan bahwa isolat P411 memiliki aktivitas selulase paling tinggi dibandingkan 11 isolatpenghasil selulaselainnya.

Isolat-isolat khamir TNGH penghasil selulase didominasi oleh khamir berfilamen. Hasil analisis Tabel 1 menunjukkan sebanyak
11 isolat khamir memiliki filamen, dan hanya satu isolat yang tidak memiliki filamen. Aprilismulan (2005) juga melaporkan bahwa 16 isolat khamir TNGH penghasil selulase, 13 isolat di antaranya memiliki filamen. Menurut Lynd et al., (2002), fungi yang berfilamen memiliki kemampuan untuk menembus substrat lignoselulosa melalui perpanjangan hifa, sehingga enzim selulase yang dihasilkannya dapat langsung mencapai substrat.

\section{Penapisan menggunakan substrat spesifik}

Hasil penapisan dengan medium spesifik menunjukkan enam isolat (P411, P413, P414, $\mathrm{P} 4116$, P4139, dan P4240) menghasilkan $\beta$ glukosidase, dan satu isolat(P412) menghasilkan endoglukanase dan $\beta$-glukosidase (Tabel 2). Khamir yang memiliki aktivitas selulase pada substrat spesifik akan menghasilkan zona bening di sekitar koloninya (Kader et al., 1999). Zona bening di sekitar koloni khamir terbentuk karena Congo red tidak berikatan lagi dengan polisakarida yang sudah didegradasi oleh enzim selulase.

Tabel 2. Hasil penapisan aktivitas selulase menggunakan substrat spesifik (Avisel, CMC, dan Selobiosa) 0,1\% $(\mathrm{b} / \mathrm{v})$ pada suhu ruang $\left(20-25^{\circ} \mathrm{C}\right)$ selama enam hari

\begin{tabular}{|c|c|c|c|c|c|c|c|c|c|c|c|c|c|}
\hline \multirow[b]{2}{*}{ No } & \multirow[b]{2}{*}{ Kode Isolat } & \multicolumn{3}{|c|}{ Avisel } & \multicolumn{3}{|c|}{ CMC } & \multicolumn{3}{|c|}{ Selobiosa } & \multicolumn{3}{|c|}{ Medium Kontrol } \\
\hline & & $\begin{array}{c}\text { Koloni } \\
(\mathbf{m m})\end{array}$ & $\begin{array}{c}\text { Zona } \\
\text { Bening } \\
(\mathrm{mm}) \\
\end{array}$ & IAS & $\begin{array}{c}\text { Koloni } \\
(\mathrm{mm})\end{array}$ & $\begin{array}{c}\text { Zona } \\
\text { Bening } \\
(\mathrm{mm}) \\
\end{array}$ & IAS & $\begin{array}{c}\text { Koloni } \\
(\mathbf{m m})\end{array}$ & $\begin{array}{c}\text { Zona } \\
\text { Bening } \\
(\mathrm{mm}) \\
\end{array}$ & IAS & $\begin{array}{c}\text { Koloni } \\
\text { (mm) }\end{array}$ & $\begin{array}{c}\text { Zona } \\
\text { Bening } \\
(\mathrm{mm}) \\
\end{array}$ & IAS \\
\hline 1 & $\mathrm{P} 411$ & 0 & 0 & 0 & 0 & 0 & 0 & 23,15 & 27,94 & 0,206 & 0 & 0 & 0 \\
\hline 2 & P412 & 0 & 0 & 0 & 22,9 & 27,63 & 0,21 & 15,42 & 18,28 & 0,19 & 0 & 0 & 0 \\
\hline 3 & P413 & 0 & 0 & 0 & 0 & 0 & 0 & 23,56 & 28,45 & 0,207 & 0 & 0 & 0 \\
\hline 4 & P414 & 0 & 0 & 0 & 0 & 0 & 0 & 11,75 & 13,69 & 0,17 & 0 & 0 & 0 \\
\hline 5 & $\mathrm{P} 415$ & 0 & 0 & 0 & 0 & 0 & 0 & 0 & 0 & 0 & 0 & 0 & 0 \\
\hline 6 & P4116 & 0 & 0 & 0 & 0 & 0 & 0 & 12,55 & 14 & 0,11 & 0 & 0 & 0 \\
\hline 7 & P4139 & 0 & 0 & 0 & 0 & 0 & 0 & 15,25 & 18,06 & 0,18 & 0 & 0 & 0 \\
\hline 8 & P4240 & 0 & 0 & 0 & 0 & 0 & 0 & 9,75 & 11,19 & 0,15 & 0 & 0 & 0 \\
\hline 9 & P4319 & 0 & 0 & 0 & 0 & 0 & 0 & 0 & 0 & 0 & 0 & 0 & 0 \\
\hline 10 & M4148 & 0 & 0 & 0 & 0 & 0 & 0 & 0 & 0 & 0 & 0 & 0 & 0 \\
\hline 11 & M4151 & 0 & 0 & 0 & 0 & 0 & 0 & 0 & 0 & 0 & 0 & 0 & 0 \\
\hline 12 & L4225 & 0 & 0 & 0 & 0 & 0 & 0 & 0 & 0 & 0 & 0 & 0 & 0 \\
\hline 13 & $\begin{array}{c}\mathrm{P} 2112 \\
\text { (kontrol positif) }\end{array}$ & 0 & 0 & 0 & 22,21 & 26,76 & 0,205 & 16 & 19 & 0,19 & 0 & 0 & 0 \\
\hline 14 & $\begin{array}{c}\text { UICC Y-17 } \\
\text { (kontrol negatif) }\end{array}$ & 0 & 0 & 0 & 0 & 0 & 0 & 0 & 0 & 0 & 0 & 0 & 0 \\
\hline 15 & Kontrol Medium & 0 & 0 & 0 & 0 & 0 & 0 & 0 & 0 & 0 & 0 & 0 & 0 \\
\hline & $\begin{aligned} \text { erangan: } & \text { IAS } \\
& \mathrm{d}(\mathrm{mm}) \\
& \text { Diamet }\end{aligned}$ & er kolon & & $\begin{array}{l}\text { Indel } \\
\text { diam } \\
\text { Dian }\end{array}$ & $\begin{array}{l}\text { Aktivi } \\
\text { er zona } \\
\text { er luar }\end{array}$ & $\begin{array}{l}\text { tas Selul } \\
\text { bening } \\
\text { silinder }\end{array}$ & & & & & & & \\
\hline
\end{tabular}


Isolat P415, P4319, M4148, M4151, dan L4225 tidak terdeteksi menghasilkan komponen selulase setelah enam hari ditumbuhkan pada medium spesifik. Hal ini berbeda dengan hasil penapisan aktivitas selulase dengan selulosaazur menunjukkan isolat P415 dan M4148 mampu menghasilkan selulase pada hari ke-5 pertumbuhan, tetapi enzim yang dihasilkannya sedikit. Hal tersebut diindikasikan dengan rendahnya intensitas difusi azur selama penapisan. Intensitas difusi azur kedua isolat tersebut tetap rendah hingga hari ke-14, (ungu pucat). Tidak terdeteksinya aktivitas komponen selulase pada kedua isolat tersebut mungkin karena rendahnya konsentrasi enzim yang dihasilkan. Isolat P4319, M4151, dan L4225 juga tidak menghasilkan aktivitas selulase pada substrat spesifik. Hasil penapisan aktivitas selulase dengan selulosa-azur menunjukkan bahwa isolat P4319 menghasilkan selulase pada hari ke-7, isolat P4151 pada hari ke-14, dan isolat L4225 pada hari ke-12. Ketiga isolat tersebut kemungkinan belum menghasilkan komponen-komponen selulase pada hari ke-6 penapisan dengan substrat spesifik.

Tabel 2 menunjukkan bahwa sebanyak enam isolat khamir (P411, P413, P414, P4116, $\mathrm{P} 4139$, dan P4240) menghasilkan $\beta$-glukosidase dan satu isolat khamir (P412) menghasilkan endoglukanase dan $\beta$-glukosidase. Sebagian besar isolat khamir TNGH yang diteliti oleh Aprilismulan (2005) juga menghasilkan endoglukanase dan $\beta$-glukosidase. Menurut Lachance dan Starmer (1998), khamir umumnya menggunakan sumber karbon dari senyawa-senyawa organik sederhana, seperti nektar dan senyawa-senyawa hasil degradasi. Hal tersebut mungkin yang menyebabkan khamir umumnya tidak menghasilkan ketiga komponen selulase yang dibutuhkan untuk menghidrolisis senyawa kompleks seperti selulosa.

Campbell (1987) melaporkan bahwa khamir banyak ditemukan pada bagian-bagian tumbuhan, seperti daun, bunga, dan buah. Dekkera intermedia (Blondin et al., 1983) dan C. pelliculosa (Kohchi et al., 1985) merupakan contoh khamir penghasil $\beta$-glukosidase yang ditemukan pada tumbuhan. Smith (1998) melaporkan bahwa $D$. intermedia van der Walt dapat ditemukan pada buah anggur, sedangkan
C. pelliculosa Redaelli ditemukan dari getah pohon Prunus (Kurtzman, 1998).

Hasil dari penelitian ini, isolat-isolat khamir dari tumbuhan TNGH sebagian besar menghasilkan $\beta$-glukosidase. Penelitian lebih lanjut diperlukan untuk mengetahui kondisi optimum dalam produksi enzim dan karakter enzim yang dihasilkan agar enzim dapat dimanfaatkan untuk industri yang tepat.

\section{Kesimpulan}

Penapisan aktivitas selulase 236 isolat khamir TNGH menggunakan selulosa-azur $0,2 \%$ (b/v) selama 30 hari menunjukkan bahwa sebanyak 12 isolat memiliki aktivitas selulase. Penapisan menggunakan substrat spesifik (CMC, Avisel, dan selobiosa) selama enam hari pada 12 isolat penghasil selulase menunjukkan bahwa enam isolat menghasilkan enzim $\beta$-glukosidase, dan satu isolat (P412) menghasilkan endoglukanase dan $\beta$-glukosidase. Lima isolat tidak terdeteksi menghasilkan ketiga komponen enzim selulase sampai hari ke-6.

\section{Daftar Pustaka}

Aprilismulan. 2005. Penapisan, optimasi, dan karakterisasi selulase khamir dari Taman Nasional Gunung Halimun. Tesis Departemen Biologi FMIPAUniversitas Indonesia, Depok.

Bayer, E.A., Chanzy, H., Lamed, R. and Shohan, Y. 1988. Cellulose, celulase and cellulosomes. Current Opinion in Structural Biology 8: 548667.

Blondin, R., Ratomahenina, R., Arnaud, A. and Galzy, P. 1983. Purification and properties of the $\beta$ glucosidase of a yeast capable of fermenting cellobiose to ethanol: Dekkera intermedia Van der Walt. Europ. J. of App. Microbiol and Biotechnol 17: 1-6.

Campbell, R. 1987. Plant microbiology. Edward Arnold (Publisher) Ltd. London.

Fanny. 2004. Penapisan aktivitas selulase khamir dari tumbuhan dan serasah asal hutan mangrove Cagar Alam Muara Angke dan Pulau Rambut, Jakarta Utara. Skripsi Departemen Biologi. Fakultas Matematika dan Ilmu Pengetahuan Alam. Universitas Indonesia, Depok. 
Lachance, M.A. and Starmer, W.T. 1998. Ecology and yeasts. In: Kurtzman, C.P. and Fell, J.W (Eds.). The yeasts, a taxonomic study. $4^{\text {th }} \mathrm{ed}$, pp. 21-30. Elsevier, Amsterdam.

Kader, A.J. and Omar, O. 1998. Isolation of cellulolytic fungi from Sayap-Kinabalu Park, Sabah. Serawak. ASEAN Review of Biodiversity and Environmental Conservation.

Kader, A.J., Omar, O. and Feng, L.S. 1999. Isolation of cellulolytic fungi from the Barito Highland, Serawak. ASEAN Review of Biodeversity and Enviromental Conservation.

Kohchi, C., Hayashi, M. and Nagai, S. 1985. Purification and properties of Candida pelliculosa var. acetaetherius. Agric. and Biol. Chem. 49 (3): 779-784.

Kurtzman, C.P. 1998. Pichia E.C. Hansen emend. Kurtzman. In: Kurtzman, C.P. and Fell, J.W. (Eds.). The yeasts, a taxonomic study. $4^{\text {th }} \mathrm{ed}$, pp. 273-325. Elsevier, Amsterdam.

Lynd, L.R., Weimer, P.J., van Zyl, W.H. and Pretorius, I.S. 2002. Microbial cellulose utilization: Fundamentals and biotechnology. Microbiol and Molecul Biol. Reviews 66 (3): 506-577.

Onsori, H., Zamani, M.R., Motallebi, M. and Zarghami, N. 2005. Identification of over producer strain of endo- $\beta$-1,4-glucanase in Aspergillus species: characterization of crude carboxymethyl cellulase. African $J$. of Biotechnol 4 (1): 26-30.

Saha, B.C. and Bothast, R.J. 1996. Production, purification, and characterization of a highly glucose-tolerant novel $\beta$-glucosidase from Candida peltata. Appl. and Environ. Microbiol. 62 (9): 3165-3170.
Smith, M.Th. 1998. Dekkera van der Walt. In. Kurtzman, C.P. and Fell, J.W. (Eds.). The yeasts, a taxonomic study. $4^{\text {th }}$ ed, pp. 174-177. Elsevier, Amsterdam.

Smith, R.E. 1977. Rapid Tube Test for detecting fungal cellulase production. Appl. and Environ. Microbiol 33 (4): 980-981.

Sudiana, I.M. and Rahmansyah, M. 2002. Species and functional diversity of soil micoflora at Gunung Halimun National Park. BCP JICA.

Teather, R.M. and Wood, P.J. 1982. Use of congo red polysaccharide interactions in enumeration and characterization of cellulolytic bacteria from the bovine rumen. Appl and Environ. Microbiol 43 (4): 777-780.

Yosylina. 2004. Penapisan aktivitas selulase khamir dari moluska (fam. Ampulariidae dan potamididae) asal hutan mangrove Cagar Alam Muara Angke dan Pulau Rambut, Jakarta Utara. Skripsi Departemen Biologi. Fakultas Matematika dan Ilmu Pengetahuan Alam. Universitas Indonesia, Depok.

van der Walt, J.P. and Yarrow, D. 1984. Methods for the isolation, maintenance, classification and identification od yeast. In: Kreger-van Rij (Eds.). The yeast a taxonomic study $3^{\text {rd }}$ rev.ed, pp. 45-105. Elsevier Science Publisher B.V. Amsterdam. 